\title{
Gender And Political Participation In Pakistan: Issues And Constraints
}

\author{
Rukhsana Hassan \\ Department of Gender Studies \\ Fatima Jinnah Women University \\ Saima Keyani \\ Department of Defence \& Diplomatic Studies \\ Fatima Jinnah Women University
}

\begin{abstract}
In order to achieve the objectives of poverty alleviation, sustainable development, and even human resource development it is imperative that women should be a part of governance and decision making bodies at all levels. In Pakistan too since independence, like other countries of the world, over the period of last six decades different regimes, both civil and military, have attempted to integrate women in the political process of the country. In the year 2000 under the patronage of the military regime, Pakistan has made significant progress in enhancing women's political participation. In the local government ordinance of 2001 women representation in the different tiers of local government was raised to $33 \%$. Regardless of this progress women access to the political institutions is not without constraints. Data for the research was collected, through interviews and close ended questionnaires, from 20 women parliamentarians. The major constraint, according to the respondents, is the mindset which women have to face in order to participate in the political process. The mindset is based upon the stereotypical division of roles and domain into male and female, which restrict women's roles to domestic sphere and deter their participation in the public life. Although, women parliamentarian did acknowledge the role of family support in overcoming barriers to women participation in the political process, still in $21^{\text {st }}$ century this support is not available to majority of women in Pakistani society. Apart from it role of media and the support of political parties are two other important dimensions which play an important role in creating barriers to women participation in the political process.
\end{abstract}

Keywords: Issues, women parliamentarian, political participation, Pakistan

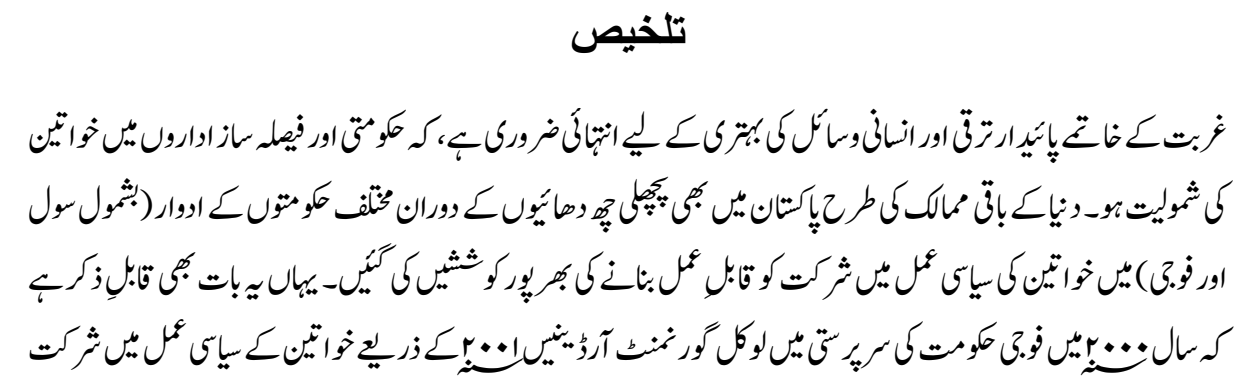




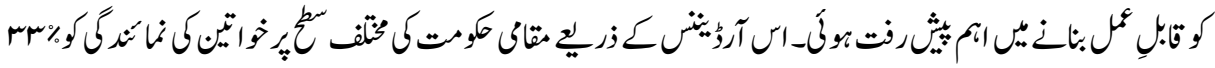

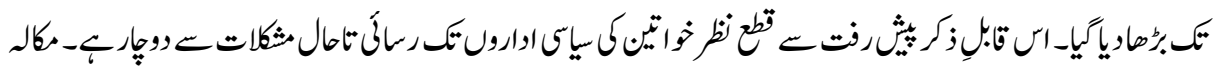

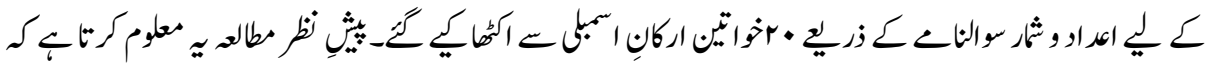

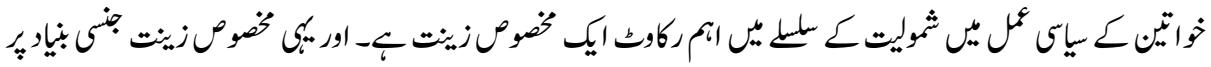

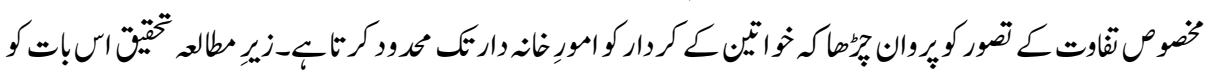

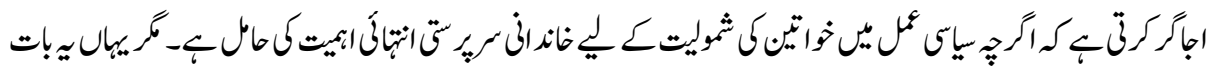

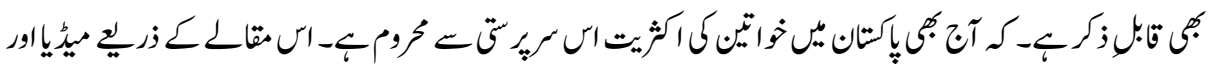

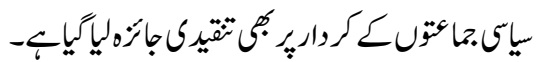

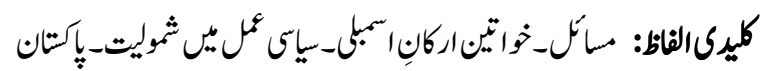

The seed of democracy lies in the principle that the legitimacy of the power to make decisions about peoples' lives, their society and their country should derive from a choice by those who will be affected. For many centuries the basis of this legitimacy was limited and many were excluded from making a choice ..overwhelmingly, women.

FreneGinwala (2005)

\section{Introduction}

In order to achieve the objectives of poverty alleviation, sustainable development, and even human resource development it is imperative that women should be a part of governance and decision-making bodies at all levels. Nadezhda Shvedova (2005) has pointed out that in the year 2005, women around the world held only $16 \%$ of the parliamentary seats, indicating their under representation in parliament, as well as their lack of involvement in the decision-making levels of the governance. It has been documented that women's increased involvement in power structures is imperative in order to rectify gender inequities within societies (Bari, 2005). The awareness regarding the importance of female representation in the political process and the historic omission of women from power structures, is because of the efforts of feminist movement and of international development organizations, donors, and institutions, including CIDA, DFID, WTO IMF and World Bank for gender equality and elimination of discrimination against women and other marginalized communities (Jabeen \& Jadoon 2009). This realization has resulted in a concerted effort for global commitment to redress gender imbalance in politics.

This awareness had led to the highlighting and recognition of the issue related to the participation of women in the political system in the framework of the Millennium 
Development Goals. Later on, the document agreed upon in 2005 world summit also reiterated the commitment for the increased participation of women in decision-making echelons, along with increasing the prospects of women active involvement in the political process. The indicator to monitor the Goal 3 on gender equality in the different societies was directly related to the proportion of women lawmakers in the different tiers of legislative forum.

It is well documented that in the $21^{\text {st }}$ century, most of those formerly barred from the political process have earned the right to vote as well as be the part of legislative bodies. However, in the emerging and time-honoured democracies alike, it has turn out to be clear that having the right to vote did not in itself lead to the development of parliament which is representative in essence and as Ginwala (2005) has documented that many segments of the society, mainly women, remain excluded from the political process. Despite awareness about the role of women in policy making bodies, women representation in politics around the world is exceedingly low, because of discrimination, inequality and the ideology of sexual division of labor. It is a fact that having rights in legislation does not entail those women can claim and make use of those rights.

Women comprise 50 percent of the world's population as well as of labour force, yet, as discussed by Ballington (2005:24), they constitute more than one billion human beings who live below poverty line. It has been documented that by virtue of women's dual role, both in the domestic and economic sphere, the contribution of women in the socioeconomic development of societies is also more than half (Bano 2009). The human development report (1995b) has also revealed the same finding that women share the major burden $(70 \%)$ of world's poverty, because of less economic opportunities, longer working hours, and lower income as compare to similarly situated men. The assessment of South Asian countries on gender related development index, in the abovementioned Human Development report, the region on the whole was ranked as one of the lowest in the world. Therefore gender equality in all walks of life, has been recognized as the key strategy of development framework and it has also been realized that without including women in the process of governance no society can achieve the goals of human development (Jabeen \& Jadoon, 2009; UNDP, 2008; Kama,1 2000; Cheema, 2000).

Democracy requires every citizen, especially women, should have equal access and full participation in all spheres of public life, particularly at executive positions and policy implementation forums to enhance their own as well as societies' development (Jabeen \& Jadoon, 2009; Haque \& Zafarullah, 2006; Rondinelli, 2006; Haque, 2003). Conventions, like Beijing Platform For Action (PFA) and the convention on the elimination of all forms of discrimination against women (CEDAW) ${ }^{1}$ have placed a general emphasis on increasing the number of women at local and national levels of decision making.Hence an effective democracy, by definition, has to be gender sensitive with an objective to make 
every effort towards achieving equality in all spheres of life as well as equal representation of women and men in decision making processes.

There is no restriction on the women's political participation in the 1973 Constitution of Pakistan; however, their number in the political parties as well as at different tiers of political structure, remains insignificant due to socio-cultural norms and structural barriers. The main theme of the paper is to identify the major impediments women confront when they opt to enter the political process, as well as once they are part of the legislative bodies? To what extent their voices are heard in the decision making processes within the party and in the parliament? What strategies women parliamentarians proposed which can influence the parliamentary political process? There are numerous factors, like socio-cultural norms, nature of political structure, geographical characteristics and level of economic development, that play a crucial role in hampering or facilitating women's political participation. Women who want to enter in politics and those who are already present in the legislative assemblies have observed that the public, socio-cultural, and political environment is generally in hospitable and at times often intimidating to them.

\section{Theoretical Framework}

The last 3 decades of $20^{\text {th }}$ century has seen a significant transformation with respect to women's participation in political, socio-economic, and administrative fields, as Jabeen \& Jadoon (2009) has stated that, it is one of the most remarkable developments of $20^{\text {th }}$ century. According to the report of Inter-Parliamentary Union (1997) the period during 1987-1995 has witnessed an increase in number of countries with women ministers. It has also documented that there are about ten countries where women hold more than twenty percent of positions at ministerial level (Jabeen \& Jadoon, 2009). Despite this improvement in the women's representation statistics are not so promising as data has shown that by 2007 , the average percentage of women around the world in the legislative assemblies was only sixteen percent and only 7 women were able to reach the ladder of head of state and government, where as only $9 \%$ of ambassadors to the UN were women. According Paxton \& Hughes (2007), women comprise around seven percent of the Cabinet ministers, and only eight percent of Mayors around the world. In the year 2008, globally, women representation in the parliament was around $18 \%$ which indicate a slight overall increase (Bano, 2009). However, their involvement in formal political procedure, where major decisions related to policy formation and the use of collective public resources are planned, remains trivial and when it comes to decision making aspect about an issue it is mainly in the hands of men (Bari, 2005).

This underrepresentation of women in parliaments worldwide indicates that political values and behaviours are, in fact, gendered. As historically marginalized group, women 
traditionally have been left out of political life. Scholars have identified political, social, economic, and cultural factors shaping women's access to the parliament and political process (Tripp \& Kang, 2008). It has been pointed out in different studies that parliaments which have continuously focused on women issues and needs in their parliamentary procedures are the ones having considerable ratio of women parliamentarians, and where women held the portfolios of leading positions, like speakers and deputy speakers.

It is beyond the scope of this article to discuss the reasons of women underrepresentation in the politics as well as in the political process and as Catalono (2009:49) has stated that relating underrepresentation to deep-rooted patterns of social -cultural norms, along with direct and indirect discrimination, will be a very simplified explanation. Women today continue to bear the main caretaking responsibilities at home and at the workplace women face indirect discrimination in the form of gender discriminatory policies, which may not be priority agenda of male members of parliament, like gender friendly working hours, and work place nurseries, and day care facilities.

Discussing the political participation of women NadezhdaShvedova (2005) have pointed out that at the start of the Twenty first century, there has been an overall improvement in the political standing of women around the world as ninety five percent of all countries in the world have granted women the two most basic democratic rights, i.e., the right to vote and the right to contest the elections. However with modernization and renaissance period, philosophers and leaders (both Western and non western) of $19^{\text {th }}$ and $20^{\text {th }}$ centuries started debating the nature of citizen's political rights and women's involvement in the political process. This is because of the fact that modern women contribute more in social and economic development of their societies yet their representation at the decision making institutions remains insignificant (Bari 2005). Keeping the prevailing scenario in view the international community took bold initiatives to increase participation of women in the political process. Still, at the end of the first decade of $21^{\text {st }}$ century the situation is not so promising. The low level of representation of women in parliaments in many countries of the world is more a manifestation of a status quo. According to Shvedova (2005) in most countries de jure complications are because of two major issues which are related to the lack of implementation of existing laws or non-existence of laws related to female participation in the political process.

Discussing the issue of sustentative and constitutive representation in the parliament (Childs, Webb \& Marthaler, 2010) various researches have also focused on the characteristics of legislators and their representativeness, i.e., whether representatives from underrepresented groups have same characteristics or are they different from traditional political elites. In other words are they bringing non traditional social backgrounds, different educational, work and political experiences to the elected office? 
(Schwindt-Bayer, 2011, 2010, Best \& Cotta, 2000; Carroll, 1994; Dodson, 1997), why they are similar or different, and what the implications are for representation (Norris 1996; Norris\& Franklin, 1997).

A study by Schwindt-Bayer (2011) on women participation in Latin America has indicated those legislators' backgrounds, and political experience has important implications for substantive representation. Therefore while discussing the role and participation of women parliamentarian we need to take into account the characteristics of the parliamentarians also, like who the representatives are? What they have experienced on the road to the national legislature? And how they view their political future motivates their policy preferences, the legislation they work to pass, and the way they relate to their constituents. Gender differences in these characteristics could explain differences in the way representatives "act for" their constituents (Schwindt-Bayer, 2006, 2010; Taylor-Robinson \& Heath, 2003). Bicquelet, Weale, Bara (2012) in their research on the issue related to the importance of political representation of women have raised the question like, to what extent women and men behave and interact in different ways in the parliamentary setting on a particular issue? Their research has supported the earlier researches that women parliamentarians generally focussed on "women issues" (Bird 2005; Childs 2000) and "provide further insight into the manner and content of argumentation".They have further indicated that men and women care about same issues, but think about them in different ways (Bicquelet, et al. (2012:117).

There is a debate among the scholars working on women parliamentarians, their participation in the political process and their representativeness, i.e., whether higher number of women in the parliament substantively represent women issues? (Childs, Webb \& Marthaler, 2010; Childs, 2006). According to Childs \& Krook (2009) large number of women in the legislative assemblies can generate healthy debates about women issues along with subsequent changes in proposals, and debates, whereas other studies have found little or no difference. Discussing the same issue, Bicquelet, Weale, Bara (2012:83) have stated very clearly, that arguments for more women representatives in parliament are not about statistical parity, but are rather based on the claim about the unique insight and understanding that women parliamentarians bring to political debate and decisions. The strategy to introduce quotas for electoral seats, was implemented in various countries in order to address the issue of women under representation in the parliament. The strategy of allocating quota, has received approval as well as critical evaluations by the scholars. The idea behind the implementation of quota system was based on the premise that it will act as a tool and will enable the governments to uphold minimum of thirty percent of women at all tiers of decision making (Krook, Mona Lena, 2009). Those who disapprove the quota system based their argument on two grounds, one argument is based on the belief that quota system leads to in equity and is not compatible with equality between men and women. The second argument is based on the idea that 
quota system only works if female participators are placed in a favourable situation specifying the placement of women candidates in winnable constituencies.

It has also been argued that quota system may encourage the selection of inept candidates who may not be able to serve the cause of democracy, in general and of women in particular. The research on gender quotas in Latin American legislatures has raised questions about whether women elected under quotas are mere "tokens" or are wellqualified and politically ambitious representatives (Franceschet \& Piscopo, 2008; Krook, Mona Lena, 2009; Murray, 2010). Similarly, as pointed out by Jabeen \& Jadoon, (2009:271), the concept of specially specified women seats in the legislature has also attracted criticism as it is believed that it will place women at a disadvantaged position with respect to men who are elected directly in general elections. It is generally assumed that the women parliamentarians elected on quota system or on reserved seats are generally considered to be submissive vote banks and reserve representatives of male parliamentarians (Jabeen \& Jadoon, 200; Reyes, 2002; Drage, 2001). This perception of being passive vote banks further on creates impediment for women parliamentarians to gather whole hearted support of other members of the parliament, their own parties, and access to knowledge and information necessary for effective involvement (Jabeen \& Jadoon, 2009). Discussing the impact of gender quota in Rwanda, Burnet (2011) is of the opinion that in case of Rwanda initiating the policy of gender quotas in political process and equality policies in other walks of life has resulted in significant cultural changes related to the attitudes toward, and perceptions of, women and their competence.

Historically, two reasons are cited for the women's minimal participation in politics:

1. Women are not capable to handle political, administrative and government matters rationally. They are emotional, compassionate, liberal, shortsighted with no reasoning, weak, and are inferior to men ${ }^{2}$ therefore they are considered to be more proficient at dealing with issues related to healthcare, social welfare (Hayes, 2011; Matland \& Tezcur, 2011; Huddy \& Terkildsen, 1993; Leeper, 1991). Men on the other hand are perceived to be more competent, tough, articulate and ambitious. This perception of men is reflected in limited participation of female parliamentarians in the process of decision making, policy formulation on the issues of national security and foreign policy, as well as in the policy implementation forums (Jabeen \& Jadoon, 2009; Hayes, 2011; Herrick Sapieva, 1997; Lawless, 2004, Alexander \& Anderson, 1993).

2. Women place is at home and they are supposed to take care of their children, husband and family (Jabeen \& Jadoon, 2009). They are responsible for the comfort of their families and rearing of their children.

As long as the sexual division of labour remains unbalanced, it is difficult to imagine that women will be able to manage a full-time career in politics and running for political 
office as politics was defined with regard to public sphere which is contradictory to general perception of women place is in private sphere (Jonasdottir \& Drude, 1998). This division of role has repercussion for women in terms of prospects available to them for their personal and professional growth.

\section{Women in Politics of Pakistan}

Muslim women played a major role in the creation of Pakistan. The struggle to politically empower Pakistani women was initiated soon after Independence. The founder of Pakistan, Quaid-e-Azam Muhammad Ali Jinnahhad a firm belief regarding women's role in the socio-economic development of the society and was convinced that the liberation of Muslim men is unattainable unless Muslim women share the struggle as equal partner. Regardless of Quaid's vision, the participation of Pakistani women in the Legislative Assemblies of Pakistan has been uneven since 1947.

In light of women's invisibility in Pakistani political process, throughout the constitutional history of Pakistan from 1956 to 1973, there has been a continuous pattern with respect to the provision of reserved seats for women in parliament. In the constitution of 1956, three percent quota for women was approved. The constitution of 1956 also specified the provision for reserving ten seats for women for a period of ten years. The number of the seats was, equally divided between East and West Pakistan (PILDAT, 2004). Under the constitution of 1973, elections of 1977 were held, but within months the assemblies were dissolved, resulting in the imposition of Military Rule in July 1977. In 1981, General Zia ulHaq's nominated Majlis-e-Shoora (Federal Advisory Council) also inducted twenty women members (Jabeen \& Jadoon, 2009; Bano, 2009). During 1985 elections of National Assembly which were held on non party basis, women's reserved quota was doubled to twenty percent. In the elections, that were held in 1988, the reserved quota for women's seats remained unchanged. This provision of reserved quota was expired before the elections of 1990 and has not been revitalized, despite commitments by the politicians of major political parties in their election manifestos.

Although the successive regimes did try to institutionalize the women development and participation in every field, like Women Division, Women Police station, First women Bank, First women University, Ministry of Women, increased reserved seats for women along with different pro women legislations. Although with the increased participation of women in every field, women in politics are underrepresented in Pakistan. According to statistical data of women in national parliaments has indicated that in Lower house (National Assembly) women representation is $22.5 \%$ and in Upper House, (Senate) the percentage is $17.0 \%$. Following are the few obstacles and constrains which a Pakistani women face to make inroad in parliament (Ballington \& Karram, 2005).

1. Socio-Economic constrains 
2. Ideological and Psychological constrains

3. Political constrains

Every society is based on hierarchy and the class defines the status or position of a person in specific society. Socio-economic status (SES) basically determines the position of an individual in a society. Factors like income, education and occupation determines the SES of an individual in a society. The Pakistani women are not a homogenous category. It has been documented that in Pakistan, there is substantial diversity among women on the basis of class, region, ethnic and religious groupings. However, in case of Pakistan women's position vis-à-vis men is one of universal subordination, determined by patriarchy (Bari, 2005).

Pakistani society is a patriarchal society where man defines and decide the fate of a woman either in relation to father, brother, husband or son. Even the educated families the men do have to some extent upper hand as compare to the women. In such kind of culture gender disparities are bound to exist in health, education, participation in the labor force and representation in legislative assemblies (UNDP, 2000, 1995b). In the context of education the statistics have indicated that since 1951, the number of non-literates has doubled in Pakistan, whereas the number has rippled in case of women (Jabeen \& Jadoon, 2009; Coleman, 2004; Kamal, 2000)

However the most visible division between man and woman in Pakistan is a division on the basis of public and private arena. In private sphere woman is expected to take care of family and children and even if she is a working woman, she is expected to obediently and devotedly perform her roles as wife, mother, sister or daughter.

\section{Significance of Research}

There have been previous researches (Jabeen \& Jadoon, 2009; Bano, 2009) related to the issue of participation of Pakistani women in the political process, but these researches have mainly relied on secondary sources for information. The current work has utilized both primary and secondary sources to gain insight on the issue. The sources of information include scholarly articles, reports, both published and unpublished, as well as national \& international documents. The primary sources of data included the authors' personal communication with the parliamentarians and their feed back in the form of questionnaires. These sources enabled the authors to get insight on the issues related to women participation in the political process.

\section{Methods}

As mentioned above the present work has utilized both primary and secondary sources of data collection. The primary research included interviews with women parliamentarians 
as well as self constructed close ended questionnaire to obtain required information. The sample consisted of 20 women parliamentarians of different parties. There were no inclusion criteria for the selection of the sample, as non-probability, simple convenient sampling technique was used. There are also some limitations of the study like small sample size, limited time for the research and non availability of the respondents, limited time for interviews to name a few. Apart from it respondents were reluctant to share information regarding party and their participation in the decision making process.

\section{Result and Analysis}

The thematic analysis technique was used to analyze the data obtain from interviews and close ended questionnaires. Analysis was done keeping in view the three broader areas of constraints proposed by Ballington \& Karam (2005), whichare Socio-Economic Ideological and Psychological, and Political in nature.

\section{Socio-Economic Constraints}

\section{Limited Resources}

All the respondents pointed out that limited resources, mainly financial resources, along with training and limited support networks, as one of the major constraints which women have to face in the political system of Pakistan. The issue of limited funding and election campaign financing was a persistent theme in the responses of the majority of the respondents: as there is no system in place that can facilitate State contribution for financing of election campaigns. According to one respondent,

One of the major issues that deter women participation in the politics is lack of resources. Participation in the political process especially, contesting election has a financial toll on the family. In this day and age, because of economic crisis it is becoming extremely difficult for families, from middle socioeconomic strata, to make both ends meet so in these circumstances only those can participate in the political process who can financially capable of managing the expenses. So it eliminates the participation of middle class in politics, and in case of upper socio-economic group families generally prefer to invest in the political career of male family members

\section{Family Responsibilities and Time Constraint}

Participation in the public life requires special emphasis on time management skill. In order to cope with family and career responsibilities, constraint on time for public life (activism and mandates) is one of the major obstacles which is most frequently cited by 
all the respondents. The pervasiveness of stereotypes and traditional perceptions regarding the roles of men and women with in the private (family) and public life is also an important deterrent for women participation in the political process. All of them were of the opinion that their priority is their family rather than their career. The issue related to time is directly linked to family responsibilities, for many women it is an accepted or imposed priority. The issue is reinforced by the strict division of roles and separation of public/ private domains for males and females, respectively. It has been well documented that even in societies where gender equality has been the established, traditional gender role patterns continue to prevail, which are generally internalised and transmitted by the elderly women of the families. In the view of majority of the respondents this stereotypical perception restricts participation of women in the political process especially for those who have their electorate from more traditional and often predominantly rural societies. The responses of the parliamentarians with respect to cultural constraints and traditional attitudes which they have to face during the initial stages of their career can be summarized as: "Women should not participate in political process as their life revolves around home - women's place is in the kitchen and should deal with the issues and concerns relating to family requirements".

Other issues that were highlighted by couple of respondents are

- Inadequate day-care facilities;

- Lack of family support

- Political parties fail to adjust their meeting schedules and group discussion meetings based on the needs of the female party members.

- Socio-cultural norms that restrict women's mobility and overnight absence from home.

On the issue of family support and socio-cultural norms one of the respondent narrated, The general impression about the politics and politicians is very negative. Although decision to enter politics was my personal decision, yet it was very hard for me to finalize my decision to enter politics. I believe that, keeping in mind our socio-cultural context, it is still very difficult for a woman to convince herself to actively participate in the political process. Once she makes up her own mind, then she has to convince her family and worry about the finances. Once she is able to tackle all these issues she has to face a daunting task of applying for the ticket, where again she has to face totally different types of impediments. She has to face criticism of the media, the attitude of the male party members and other contenders against whom she is applying, who can go to any length to win the party ticket. And finally, after overcoming all these barriers, issue remains if she can earn a ticket of a winnable seat, when her 
name goes for final selection to the party leadership, she is not selected because of the fear of losing the seat.

\section{Psychological Factors}

\section{Lack of Training}

The issue related to lack of experience and training was highlighted by almost all the respondents. They were of the view that formal integrated training mechanism should have been in place. The training should be focused on informing the interested candidates about the whole electoral process stating from early-election campaigns to election and post election scenario. As per respondents replies the training should be designed upon the basis of actual needs and not upon the perceived needs. The training should also incorporate psychological factors, like enhancing self confidence, development of fighting spirit, acknowledgement of their own worth, as well as how to overcome their fear of incompetency. Some of the issues that were highlighted by majority of the respondents, which restrict women's political participation are:

- insufficient media influence and, above all,

- Lack of self-confidence

- Lack of fighting spirit

- Fear of incompetence

- -Fear of conflict with family members

- -Fear of slander and verbal violence

All these factors strengthen or are reinforced by prevailing intolerance in the society. These factors not only reveal the persistence of traditional gender stereotypes related to the social roles of males and females within the society as well as also depict the prevailing negative image of politics in the society. These aspects are compounded by the prevalence of social cultural norms that frequently undermine the accomplishments of women in various walks of life, which in turn develop the sense of low self esteem among women in public life thus enhancing the feeling of inadequacy that make women hesitant to get involved in public and political field.

\section{Lack of Motivation and the Bad Image of Politics}

Image of politics that prevails in general also deter women participation in the political process. The image of politics related to verbal violence and slander, and inadequate training goes hand in hand which not only results in lack of interest, but also the lack of faith in political activity. One respondent refers to "apprehension with the whole political milieu". Many respondents expressed discomfort with the entire political process and depicted politics as a male-dominated arena where women have little chance to succeed. 
And some of the comments by the respondents indicate the general impression of politics among the people in general and women in particular,

- $\quad$ "Lack of interest due to the intimidating environment as well as the women do not have level field playing ground and women have to face tough competition from men".

- Some relate it to the "politicians' lack of credibility" and the perception that politics is dirty". The general opinion of the respondents was "society's disillusionment with politics due to prolonged military rule and the carved image of the politicians by the special interest groups and the media during non democratic regimes as corrupt and incompetent ".

All these statements reflect the negative image of politics which is not only reflected in the media and everyday conversations but media may also be responsible for generating such image.

\section{Political Constraints}

\section{Impediments within political parties}

Almost all respondents (with the exception of 2) pointed out the issues within parties, especially in case of appointing candidates. One senior parliamentarian was of the view that the party members make less concerted effort to support women candidates". Similarly, reservations were also expressed by the respondents who believed that parties are still reluctant to give tickets of winnable seats to women fearing of loosing the seat as it is the general perception among party executives that in our socio-cultural context the voting public is hesitant to elect women candidates.

\section{Lack of Solidarity among Women}

Some respondents also mention the issue related to the lack of harmony among women parliamentarians, which is generally reflected in hesitation to vote for each other, the reason may be jealousy and fear of opposition by senior women who have ascended to positions of influence according to one of the respondent "Women who have already established their position in the political arena sometimes intrude to eliminate potential challenger" and fail to promote and support newcomer in the political process.

\section{Previous Experience at Local Level Politics}

Regarding the importance of past experience at local level politics, of potential women candidates, all respondents agreed that it does support them in their struggle to enhance their political career. Previous experience at local level term of office did facilitate and it may also endorse nomination for a regional or national term of office. This enables them to develop a network of relations, local support base which enable women to familiarize 
themselves with the constituency work. Their previous experience may also help them to be accepted by the community and will be less inclined to arouse prejudice, because their participation in the local level politics seems to be well-matched with women's household related responsibilities. As one respondent specified that parties more readily allow women to participate at local level election from their platform", majority also stated that at local level, internally, women come across less party problems.

\section{Strategies Proposed by Women Parliamentarians}

To deal with the above mentioned barriers which women have to face in politics and how women can make an impact on the political process, respondents have different opinions. All the respondents were in agreement that women effective participation in the political process can only be achieved through a concerted effort by women, whether they are in or outside the parliament. All of the respondents believed that women need to be more vocal and active and have to raise more powerful voices within their political parties as well as within their respective society as a whole to be able to take benefit of the laws and policies supporting women involvement in the political process. Some of the strategies that were highlighted by the respondents are as follows:

\section{Role of Political Parties to Enhance Women Political Participation}

Political parties are the backbone of the electoral system. Eight out of twenty respondents suggested that the parties are actually the custodian of women's access to politics. They were of the view that political parties can play a crucial role in bringing social change, especially with respect to the advancement of women in the political process. The parliamentarians who are also the member of the parties have the liability for determining and revising the legal framework that lie beneath and establish women's rights in all areas. Being members of the party they have an ability and responsibility to create awareness within the party on issues effecting women's lives and the parity between men and women. Apart from it there is a growing realization among women parliamentarians that they have to work in partnership with men as they need the support of the male members of their parties to increase the efficacy of their strategy.

They are also responsible for formulating laws affecting women's lives as well as introducing amendments to family laws that are not favourable to women. In their opinion to achieve the objective of being a effective member of the party as well as of parliament it is imperative that women should gather the support both within and outside legislative bodies. In order to strengthen their presence it is essential that they should form interest groups outside the parliament or as women's caucuses a cross party lines in the parliament as it will provide them experience as well as power base on which to build 
on. Commenting upon the strategies to be adopted to enhance women participation in the political process one parliamentarian pointed out

It is vital that women parliamentarians across the board should share our experiences, and our view. The ideal way is to be a part of women caucus which gives us a forum to discuss issues that are relevant to us but also to other women. This can provide us a platform from where we can raise our voice on a non partisan basis. This will generate trust of other women on us and will motivate them to participate in the political process. This will provide us with the feeling that ordinary women are not cut off from our struggle and we have support in our effort not we are not alone in this end favour In order to accomplish this it is imperative that we should disseminate and share our ideas, knowledge and information, at different forums of civil society as well as in academia to motivate youth to participate in the political process. Our efforts should be to make sure that women in our society are well informed.

\section{Women Parliamentarian should Update their Knowledge about the Politics and Current Issues}

All the respondents believed that for effective political participation, women parliamentarians should be well aware of the prevailing issues, both national and international, and should formulate their own well informed political opinion which they should be able to express clearly and in an appropriate manner. According to all the respondents it is essential that female parliamentarians should kept themselves well informed and should have good grip about the rules and specialized language related to the political process and political debate, respectively.

\section{Establishment of Monetary Support Mechanism for Facilitating Participation of Women in Politics}

Except four respondents all the respondents were of the view that in most of the cases politically competent women are excluded from the political process because of lack of financial resources. They were of the opinion that in order to overcome finance related issues, which hampered women access to the political forums and to encourage qualified females to participate in the national politics, the best solution is establishment of a fund which will enable women from different socio-economic status to participate in the political process. According to them the parliamentarians have a huge responsibility to 
make an effort for establish in economic support mechanism for facilitating women's political participation, as a result it will the widen the spaces for women which are considered to be selective realm reserved for men. They further stated that in order to attain parity in the political process, the responsibility lies with the political parties also that the elected women representatives, either at the national or local level, should be appointed to positions of responsibility or should be given opportunity to serve on advisory committees.

\section{Making use of Rule Strategy}

Another very important strategy that was proposed by the respondents was related to the rules of the parliament. Rule strategy, as discussed by Karam \& Lovenduski, 2005) can prove to be a very effective approach to enable women parliamentarians to actively participate in the political process. The strategy includes: knowledge of the rules, make use of the rules and amending the rules. The rules, both formal and informal, are formal specific regulations as well as informal practices and customs that administrate the way a parliament functions, including the structure of the legislative assembly and its chain of command, law-making processes, the working of the assembly, and its link to different tiers and parts of the government. As one parliamentarian has narrated:

For women to function effectively in the parliament, they must have clear understanding about the functions of the legislature and of the rules, which include both written regulations and informal unwritten procedures. They should have clear understanding of the mechanisms and procedures of the parliament and how things done in the House of Representatives. For that they should have the knowledge of the internal practices of the assembly as it will enable them to make the most of these rules. It will also facilitate them to formulate effective strategies for advancing women's interests and objectives.

Learning the rules will enable women parliamentarians to participate effectively in the working of the parliament and learn the parliamentary regulations; develop the skill of effective public speaking and powerful communication; and how to gain the support of male colleagues. The knowledge about the rules will enable them to establish their presence within different committees, related to budget, defense, and foreign affairs, to name a few. The information about the rules will also help them to influence parliamentary agendas introduce women responsive procedures, e.g. make an effort to bring changes in parliamentary work programs that it can suit and facilitate working mothers, as well as it will also enable them to highlight the absence of female parliamentarian in central committees and at key positions. Understand and handle the media for image projection and public speaking. According to a few respondents many 
women parliamentarians find it difficult to speak authoritatively and argue convincingly at public forums and in legislative chambers, participation in various trainings will also facilitate the female parliamentarians to use media effectively, which will also allow them to expand their electorate It will also facilitate them to form and extend partnership with other marginalized groups to widen their support network. The sheer presence of women in the parliament will without doubt defy the existing provisions and measures. The knowledge about the rules will facilitate the women parliamentarians to raise their concerns regarding parliamentary schedules, venue of the meetings, provision of childcare facilities, work schedule and travel arrangements in order to make them more women friendly.

\section{The Importance of Media}

There is no doubt that media play an important role with respect to portrayal of women parliamentarians, the positive or negative representation of women in politics generally had a great impact on encouraging or discouraging women's participation in the political process All the respondents were of the opinion that media can also be used as an effective strategy to facilitate women's participation in the political process. It can be used as an important tool to create awareness, as well as to inspire public opinion concerning the importance of women's participation in the politics.

According to couple of respondents "generally media is insensitive to the issues of time constraint women parliamentarians have to face and is ignorant of issues which they have to face in acquiring facilitation from the local socio-cultural environment". They also criticized the failure of media to draw attention to the prospective role of women in the political process. The respondents were of the view that women politicians are generally too concerned about the criticism by the media as a result they avoid to raise their concern on any controversial issue. Many respondents also pointed out the lack of role models for emerging female politicians. Therefore, there is a need of committed group of women journalists covering politics, who should critically analyzed the functioning of both males and females politicians and abstain from focusing on the physical appearance and private life of female politicians.

\section{Conclusions}

During the government of Zulfiqar Ali Bhutto ten percent for women in parliament was fixed. On the other hand in General Pervez Musharaf's era thirty three percent of total seats were allocated to women in local government and seventeen percent seats in the legislative bodies. In fact it has been documented that none of these regimes responded positively to women's issues. As Bano (2009) has stated women's issues and their political representation have been used by all the governments to strengthen and extend 
their own political agenda and to score their political points. In Pakistan like many other developing countries of the world women who were involved in the political process, or those elected in parliament generally belong to politicians who have been in power previously. This tendency may influence the course of action for change in the support of those who are in power. The responses of the parliamentarians have indicated that women low participation in the politics is because of the stereotype that prevails which specify that politics is not only considered as a male domain but is also projected as a 'domain associated with corruption and deceit. Women are socialized in a manner which reduces their participation in formal political processes to minimal. As mentioned above politics is generally considered as male domain and strict division of public and private spheres, women participation in the political process is generally not welcomed by the community at large. In the words of one respondent regarding her struggle during her political career (personal communication),

Despite I am a veteran politician I have a long struggle to my credit, which started a long time ago, even today it is a daily struggle. I have to cope with my family related issues and assigned roles, positive media image of competent parliamentarian and how to make my voice heard on particular issue within the parliament. Despite the progress we have made it is still nominal because male domination in the political process continues to be unrelenting. Problem is no longer in the law or in its implementation but it is the attitude and mind set,

Apart from it the constraints which restrict women participation in the political process are lack of political skill, financial resources, role models in the field and media to name a few. Increasing representation and participation of women in the decision-making structures entail well-developed plan of action.

However, it is a surmountable a challenge for women parliamentarians to play their role effectively because their participation in the political process is not yet wellacknowledged by their male colleagues as a result they have to face insurmountable opposition in carrying out functions and fulfilling their responsibilities along with exercising their authority. The respondents also pointed out various strategies which can facilitate women participation in the political process as well as in performing more effective role once they are involved in the political process. According to the respondents knowledge about the rules of political process is crucial. The awareness regarding rules will facilitate women parliamentarians to solicit support of their male colleagues on various women related issues and bring changes in laws that are not gender friendly. Various researches have indicated that the presence of women and incorporating women's concerns will without doubt challenge the existing system of political process and procedures. 
Many of the elected parliamentarians have limited or no experience in the political field and government structures. It is imperative that a kind of awareness should be created to encourage the genuine participation of women in the political process. The awareness agenda should have three goals:

- to enlighten women regarding their rights,

- to facilitate and encourage them to exhibit interest in political process and political issues,

- to educate them, to register as a voter, to cast their vote, and to contest the elections and even to cast their vote for other women.

Apart from it all the respondents indicated the importance of media for creating awareness regarding women participation in the political process and were of the opinion that media should portray positive image of the female parliamentarian along with making an effort to sensitize people regarding women participation in the public life. Women in Pakistan, because of their low social and economic position in the society are entrenched in a mesh of dependence and subordination. A large majority of women in Pakistan endure all forms of poverty. In order to improve women's status and collective perception of their limited abilities, there is a dire need to bring structural changes in the social and economic setup As per the opinion of majority of the respondents, Pakistani women have come a long way and their presence in the parliament is an indicative of this fact and women participation in the political process is a sign of stepping forward in the positive direction.

\section{End Notes}

1. Apart from these two initiatives, Vienna declaration 1993 (ratified by 171 countries), Security council resolution (CSR1325) (2000), UN Gender Mainstreaming Policy \& Strategy (2006) are some of the other International Conventions and Initiatives which have defined charter for women's rights including social, legal, political and, economic rights.

2. Women in Power and Decision-Making, http://www.un.org/womenwatch/daw/beijing/

\section{References}

ADB (1999). Asian Development Bank "Situational Analysis of Women in Pakistan-An Overview", Briefing Paper, p.14

Alexander, Deborah \& Kristi Andersen. (1993). "Gender as a Factor in the Attribution of Leadership Traits" Political Research Quarterly, vol.46:3, pp.527-545. 
Ballington, J (2005). Introduction Women in Parliament: Beyond Numbers. Editors: Julie Ballington and Azza Karam. Handbook Series, International Institute for Democracy and Electoral Assistance, pp.24-32

Ballington, Julie \& Azza Karam. (eds.). (2005).Women in Parliament: Beyond Numbers Handbook Series. International Institute for Democracy and Electoral Assistance

Bano, S (2009) Women in Parliament in Pakistan: Problems and Potential Solutions. Women's Studies Journal, vol.23:1, pp. 19-35

Bari, Farzana. (2005) "Women's political participation: Issues and Challenges" (United Nations: DAW, Expert Meeting Group, Bangkok.

Best, Heinrich, \& Maurizio Cotta, (eds.). (2000). Parliamentary Representatives in Europe 1848-2000: Legislative Recruitment and Careers in Eleven European Countries, Oxford: Oxford University Press.

Bicquelet, Weale, Bara (2012) In a Different Parliamentary Voice. Politics \& Gender, vol.8, pp.83-121

Bird, Karen. 2005. “Gendering Parliamentary Questions.” British Journal of Politics and International Relations, vol.7:3, pp.353-370.

Burnet, Jennie E (2011). Women Have Found Respect: Gender Quotas, Symbolic Representation, and Female Empowerment in Rwanda, Politics\& Gender, vol.7, pp.303-334.

Carroll, Susan J. (1994). Women as Candidates in American Politics, $2^{\text {nd }}$ ed. Bloomington: Indiana University Press.

Catalono, Ana (2009). Women Acting for Women? An Analysis of Gender and Debate Participation in the British House of Commons 2005-2007,Politics \& Gender,vol.5,pp.45-68

Cheema, G. (2000). 'A Governance Approach to Development', in H. Hye (ed.) Governance: South Asian Perspective, Karachi: Oxford University Press, pp.513543

Childs, Sarah (2006). "The Complicated Relationship between Sex, Gender and the Substantive Representation of Women" European Journal of Women's Studies, vol.13:1, pp.7-21. 
Childs, Sarah, and Mona Lena Krook (2009). Analyzing Women's Substantive Representation: From Critical Mass to Critical Actors" Government and Opposition, vol. 44:2, pp.125-145.

Childs, Sarah. (2000). "The New Labour Women MPs in the 1997 British Parliament." Women's History Review, vol.9:1, pp.55-73

Childs, Sarah; Paul Web \&Sally Marthaler (2010). Constituting and Substantively Representing Women: Applying New Approaches to a UK Case Study. Politics \& Gender, vol.6, pp.199-223

Dodson, Debra L. (1997). "Change and Continuity in the Relationship between Private Responsibilities and Public Office holding: The More Things Change, the More They Stay the Same.” Policy Studies Journal, vol.25:4, pp.569-584.

Drage, J. (2001). Women in Local Government in Asia and the Pacific: A Comparative Analysis of Thirteen Analysis, New Zealand: United Nations Economic and Social Commission for Asia.

Franceschet, Susan, and Jennifer M. Piscopo. (2008). “Gender Quotas and Women's Substantive Representation: Lessons from Argentina." Politics \& Gender, vol.4, pp.393-425.

Frene, G. (2005). Women in Parliament: Beyond Numbers. Editors: Julie Ballington and AzzaKaram. Handbook Series, International Institute for Democracy and Electoral Assistance, pp.14-18.

Haque A, Zafarullah H (2006). 'Understanding Development Governance', in A. S. Haque and H. Zafarullah (eds.) International Development Governance, London: Taylor and Francis, pp.13-50.

Haque, M. S. (2003). 'Citizen Participation in Governance through Representation: Issue of Gender in East Asia', International Journal of Public Admin, vol.26:5, pp.569590.

Hayes, Dany, (2011). When Gender and Party Collide: Stereotyping in Candidate Trait Attribution. Politics \& Gender, vol.7, pp.133-165

Herrick, Rebekah \& Almira Sapieva. (1997). "Perception of Women Politicians in Kazakhstan" Women and Politics, vol.18, pp.27-40. 
Huddy, Leonie, and NaydaTerkildsen. (1993). "Gender Stereotypes and the Perception of Male and Female Candidates." American Journal of Political Science, vol.37, pp.119-47.

Inter Parliamentary Union (1997). Democracy Still in the Making, Geneva: Inter Parliamentary Union, www.foreignpolicy.com

Jabeen, Nasira, and Muhammad Zafar Iqbal Jadoon (2009) Gender and Local Governance in Pakistan: Representation vs. Participation, International NGO Journal, vol.4:5, pp. 264-276, Accessed April 24, 2012, http:// www.academicjournals.org/INGOJ

Kamal S (2000). 'The Democracy-Poverty Nexus: Summary on Issues of Participation', Stockholm: International Institute for Democracy and Electoral Assistance (IDEA)

Krook, Mona Lena. (2009). Quotas for Women in Politics: Gender and Candidate Selection Reform Worldwide. New York: Oxford University Press.

Lawless, Jennifer L. (2004). "Women, War, and Winning Elections: Gender Stereotyping in the Post-September 11 Era" Political Research Quarterly, vol.57:3, pp.479-90.

Leeper, Mark S. (1991). "The Impact of Prejudice on Female Candidates: An Experimental Look at Voter Inference." American Politics Quarterly, vol.19, pp.248-61

Matland, Richard E, Tezcur, Gunes, Murat (2011). Women as Candidates: An Experimental Study in Turkey. Politics \& Gender, vol.7, pp.365-390

Murray, Rainbow. (2010). "Second Among Unequals? A Study of Whether France's 'Quota Women' are Up to the Job.” Politics \& Gender, vol.6, pp.93-118

Nadezhda, Shvedova (2005). Obstacles to Women's Participation in Parliament. In Women in Parliament: Beyond Numbers. Editors: Julie Ballington and AzzaKaram. Handbook Series. International Institute for Democracy and Electoral Assistance, pp.33-50

Norris, Pippa, and Mark Franklin. (1997). "Social Representation." European Journal of Political Research, vol.32, pp.185-210 
Norris, Pippa. (1996). "Women Politicians: Transforming Westminster?" In Women in Politics, ed. Joni Lovenduski and Pippa Norris. New York: Oxford University Press, pp.91-104.

Paxton, Pamela and Melanie M Hughes. (2007). Women, Politics and Power: A Global perspective, USA: Pine Forge Press.

Phillips, Anne. (1995). The Politics of Presence. Oxford: Clarendon.

PILDAT (2004) Pakistan Institute of Legislative Development and Transparency "Women Representation in Pakistan's Parliament", Lahore, p.18

Reyes S (2002). 'Quotas for Women for Legislative Seats at the Local Level in Pakistan', International Institute for Democracy and Electoral Assistance (IDEA), Stockholm, Sweden. (http://www.idea.int)and the Pacific (ESCAP

Rondinelli D (2006). 'Decentralization and Development', in A. S. Haque and H. Zafarullah (eds.) International Development Governance, London: Taylor and Francis, pp. 391-404

Schwindt-Bayer, L A (2011) Women Who Win: Social Backgrounds, Paths to Power, and Political Ambition in Latin American Legislatures, Politics \& Gender, vol.7, pp.1-33

Schwindt-Bayer, L A. (2010). "Comparison and Integration: A Path toward a Comparative Politics of Gender. Perspectives on Politics, vol.8:1, pp.177-182.

Schwindt-Bayer, Leslie A. (2006). "Still Supermadres? Gender and the Policy Priorities of Latin American Legislators" American Journal of Political Science, vol.50:3, pp.570-585.

Taylor-Robinson, Michelle M., and Roseanna M. Heath. (2003). "Do Women Legislators Have Different Policy Priorities Than Their Male Colleagues? A Critical Case Test." Women \& Politics, vol.24:4, pp.77-101.

Tripp, Aili, \& Alice Kang. (2008). The Global Impact of Quotas: The Fast Track to Female Representation. Comparative Political Studies, vol.41:3, pp.338-361.

UNDP (1995b). Human Development Report, New York: Oxford University Press. 
United Nations Development Program (UNDP) (2008). 'UNDP Gender Equality Strategy 2008-2011', New York, UNDP

Dr. Rukhsana Hassan is Chairperson, Department of Gender Studies/ Director WRRC, Fatima Jinnah Women University, Rawalpindi.

Dr. Saima Keyani is Chairperson, Department of Defence \& Diplomatic Studies, Fatima Jinnah Women University, Rawalpindi.

Acknowledgement: Authors wish to thank parliamentarian who have participated in the research despite their other commitments and busy schedule. We would also like to acknowledge the support of Mr. Summar Rao, editor Weekly Pulse, Islamabad for facilitating the research process and enabling the authors to access parliamentarian. 